\title{
The Systemic Turn and Participatory Budgeting: The Case of Rio Grande do Sul
}

\author{
Sveinung Legard ${ }^{1 \star}$ and Benjamin Goldfrank ${ }^{2}$ \\ ${ }^{1}$ Postdoctoral affiliate, Oslo Business School, Oslo Metropolitan University and ${ }^{2}$ Professor, School of \\ Diplomacy and International Relations, Seton Hall University. \\ ${ }^{*}$ Corresponding author. E-mail: lesv@oslomet.no
}

(Received 21 December 2017; revised 10 June 2020; accepted 23 June 2020;

first published online 9 October 2020)

\begin{abstract}
Participatory budgeting (PB) has been one of the most popular local democratic reforms in Latin America in recent decades. This article examines what happened to PB when it was scaled up to the state level and integrated in a participatory system in Rio Grande do Sul, Brazil (2011-14). Using theories of deliberative systems, multichannel participation, 'venue shopping' (the practice of seeking the most favourable policy venue) and countervailing power, as well as a multimethod research design, we explain how the systems approach allowed for both deliberation and direct democracy and mobilised new sectors to participate online. However, on the negative side, the different participation channels undermined each other. Social movements migrated to other spaces, leaving the budgeting process open to control by well-established, powerful public-sector groups.
\end{abstract}

Keywords: participatory democracy; deliberative democracy; participatory budgeting; Brazil

\section{Introduction}

No argument has been used so strongly against participatory democracy as that of scale. Social science classics claim that the size of modern societies makes them impossible to be governed by ordinary citizens; we need representatives, experts and overarching institutions in order to deal with complicated issues on a large scale. ${ }^{1}$ Most scholars continue to argue that participatory democracy is unfeasible above the community level because of the impracticality of involving millions of people in policymaking for whole states or nations. ${ }^{2}$ Nonetheless, since the turn of the millennium, two separate but connected trends have reinforced opposing views that question at least the strongest versions of these claims about the impossibility of scaling up.

\footnotetext{
${ }^{1}$ See for example Joseph A. Schumpeter, Capitalism, Socialism and Democracy (London: Routledge, 2010 [1943]), pp. 220-2; Max Weber, Economy and Society: An Outline of Interpretive Sociology, vol. 2 (Berkeley, CA: University of California Press, 1978 [1922]), p. 952.

${ }^{2}$ Norberto Bobbio, The Future of Democracy (Cambridge: Polity Press, 1987), chapter 2; Adam Przeworski, Democracy and the Limits of Self-Government (Cambridge: Cambridge University Press, 2010).

(C) The Author(s), 2020. Published by Cambridge University Press. This is an Open Access article, distributed under the terms of the Creative Commons Attribution licence (http://creativecommons.org/licenses/by/4.0/), which permits unrestricted re-use, distribution, and reproduction in any medium, provided the original work is properly cited.
} 
In the realm of practice, innovations in citizen participation have gained notoriety as governments around the world adopt them and attempt to scale them up. Latin America, especially, has become a centre for experimentation with new forms of local-level participation, ${ }^{3}$ enabled by decentralisation reforms and pushed by left-leaning political parties and social movements as well as by international development organisations. ${ }^{4}$ Participatory budgeting (PB) has emerged as the key example of participatory democracy's relevance in the modern world. ${ }^{5} \mathrm{~PB}$, a process of citizen participation in public budget decisions, has been one of the most fashionable local government reforms globally in recent years, gaining admiration not only from utopian sociologists and political theorists but also from the World Bank and institutionalist economists such as Daron Acemoglu and James Robinson. ${ }^{6}$ Beginning in the early 2000s, several Latin American governments began trying to scale $\mathrm{PB}$ or other participatory institutions up to the state or national level. Brazil was at the forefront of this wave, before the removal of the Partido dos Trabalhadores (Workers' Party, PT) from the presidency in $2016 .{ }^{7}$ Scholarly accounts of the challenges of scaling up participatory budgeting, however, are scarce, a lacuna this study aims to address.

In the realm of theory, scholars working in the field of deliberative democracy have taken a 'systemic turn' that involves understanding deliberative and participatory practices within the broader political system as a whole, allowing theorists to expand their studies from small-scale initiatives like citizen juries or local-level PB to large-scale polities. ${ }^{8}$ The systemic approach recognises that modern democratic forms of government contain a division of labour among many types of institutions

\footnotetext{
${ }^{3}$ Archon Fung, 'Reinventing Democracy in Latin America', Perspectives on Politics, 9: 4 (2011), pp. 85771; Maxwell A. Cameron, Eric Hershberg and Kenneth E. Sharpe (eds.), New Institutions for Participatory Democracy in Latin America: Voice and Consequence (New York: Palgrave Macmillan, 2012); Thamy Pogrebinschi, 'Democratic Innovations: Lessons from beyond the West', in Hertie School of Governance (ed.), The Governance Report 2017 (Oxford: Oxford University Press, 2017), pp. 57-72.

${ }^{4}$ Benjamin Goldfrank, Deepening Local Democracy in Latin America: Decentralization, Participation, and the Left (University Park, PA: Penn State University Press, 2011).

${ }^{5}$ Benjamin R. Barber, If Mayors Ruled the World: Dysfunctional Nations, Rising Cities (New Haven, CT: Yale University Press, 2013), pp. 307-8; Archon Fung and Erik Olin Wright (eds.), Deepening Democracy: Institutional Innovations in Empowered Participatory Governance (London: Verso, 2003).

${ }^{6}$ Jamie Peck and Nik Theodore, Fast Policy: Experimental Statecraft at the Thresholds of Neoliberalism (Minneapolis, MN: Minnesota University Press, 2015); Osmany Porto de Oliveira, International Policy Diffusion and Participatory Budgeting: Ambassadors of Participation, International Institutions and Transnational Networks (New York: Palgrave Macmillan, 2017); Daron Acemoglu and James A. Robinson, Why Nations Fail: The Origins of Power, Prosperity, and Poverty (New York: Crown, 2012), pp. 455-7.

${ }^{7}$ Fung, 'Reinventing Democracy', p. 868; Maxwell A. Cameron and Kenneth E. Sharpe, 'Institutionalized Voice in Latin American Democracies', in Maxwell et al. (eds.), New Institutions for Participatory Democracy in Latin America, p. 244; Thamy Pogrebinschi and David Samuels, "The Impact of Participatory Democracy: Evidence from Brazil's National Public Policy Conferences', Comparative Politics, 46: 3 (2014), p. 321.

${ }^{8}$ Stephen Elstub, Selen Ercan and Ricardo Fabrino Mendonça, 'Editorial Introduction: The Fourth Generation of Deliberative Democracy', Critical Policy Studies, 10: 2 (2016), pp. 139-51; John Parkinson and Jane Mansbridge (eds.), Deliberative Systems (New York: Cambridge University Press, 2012); Mark E. Warren, 'A Problem-Based Approach to Democratic Theory', American Political Science Review, 111: 1 (2017), pp. 39-53; James S. Fishkin and Jane Mansbridge, 'Introduction', Doedalus, 146: 3 (2017), pp. 6-13.
} 
playing different roles and serving different functions, and that these institutions will be more or less deliberative and may involve fewer or greater numbers of participants. Yet, if adequately coupled with and correctly sequenced among themselves and other governing institutions, deliberative institutions can increase democratic legitimacy by enhancing the inclusion and empowerment of citizens, the quality of policy, and the responsiveness of policymakers. According to James Fishkin and Jane Mansbridge, rising nativist populism and declining trust in representative institutions and renewed authoritarianism only strengthen the need for more deliberative systems of government. ${ }^{9}$

This article focuses on the confluence of these trends. We examine a particularly interesting and important case - an attempt to scale up PB to the state level by including it within a system of deliberative and participatory institutions created by the government in Rio Grande do Sul called the 'Sistema Estadual de Participação Popular e Cidadã' (State System of Popular Citizen Participation; Sistema hereafter). This Brazilian case is interesting theoretically because it offers one of very few opportunities to examine an explicit attempt to create a large-scale deliberative and participatory system, allowing us to assess the ongoing debate between deliberative democrats and participatory democrats. This article provides an original empirical investigation of such a system in a field that has hitherto been dominated by theoretical discussions. The practical importance of this case stems in part from its location. Rio Grande do Sul's capital city, Porto Alegre, is considered the official birthplace of $\mathrm{PB}$, which has spread to over 7,000 localities worldwide. ${ }^{10}$ Recreation of PB's success at the state level could have turned the Sistema into a similarly transferable model.

Our empirical question concerns what happens to a successful local-level participatory initiative when scaled up as part of a wider deliberative system. Initially, from 1999 to 2002, the state government essentially copied Porto Alegre's local version of $\mathrm{PB}$. Through municipal assemblies and the election of delegates, participants discussed and decided how to spend the state's investment money. A dozen years later, in 2011, the state government introduced the Sistema, which not only used PB for part of the state's investment budget, but also added multiple other channels of public engagement on a range of policy issues. The two instances of PB managed the complexity stemming from increased scale in different ways. In the first case, the approach was one of unification, where major policy issues were assigned to one institution, and where it was up to the participants to assign priorities and connect the dots between the various investment areas in a holistic manner. The second case was one of diversification, where the policy issues were spread across numerous offline and online institutions, granting citizens the opportunity to debate the details of multiple policies using different deliberative venues.

Each approach had advantages and disadvantages. The unification approach has been analysed in previous works, and we have clear notions of the benefits and

\footnotetext{
${ }^{9}$ Ibid.

${ }^{10}$ Nelson Dias and Simone Júlio, 'The Next Thirty Years of Participatory Budgeting in the World Start Today', in Nelson Dias (ed.), Hope for Democracy: 30 Years of Participatory Budgeting Worldwide (Faro: Oficina, 2018), p. 19.
} 
problems associated with it. ${ }^{11}$ Mainly, it gave citizens the opportunity to deliberate on a range of issues by attending only one process. It also represented social movements and disadvantaged groups fairly well. However, there was not enough time to deal with the whole range of issues in local assemblies, and PB organisers did not have technologies to facilitate communication and coordinate the participants' decisions across hundreds of municipalities. Moreover, it provoked fierce opposition party backlash.

The diversification or systems approach to scaling up PB is less understood. This article's original contribution is to explain the advantages and disadvantages of the diversification approach using theories of deliberative systems, multichannel engagement, 'venue shopping' (the practice of seeking the most favourable policy venue) and countervailing power. In general, diversification allowed for in-depth deliberations in some channels while simultaneously retaining a strong element of mass participation. The addition of online voting also managed to mobilise sectors of the population that would not otherwise have become engaged. The central disadvantage was that the different channels of the participatory system undermined each other. Since power was distributed across the system, citizens dispersed across various venues in order to influence state policies, leaving each channel vulnerable to domination by groups with the most resources, time and organisational capacity. Social movements, always vital for a well-functioning PB, migrated to other spaces and left the budgeting process open to powerful established groups. High-ranking politicians and allied public-sector workers essentially displaced lower-class social movements. In sum, we argue that one important outcome of the Sistema was a kind of elite capture of $\mathrm{PB}$ and the concomitant erosion of countervailing power.

To be clear from the outset, we do not claim that scaling up participatory democracy is unfeasible. In a state of 11 million inhabitants, over a million riograndenses participated annually in the Sistema's PB from 2011 to 2014, helping to decide the allocation of hundreds of millions of reais in investment spending. Our argument is rather that participatory or deliberative democrats wishing to scale up local initiatives face distinct challenges and trade-offs. Different forms of scaling up have different advantages and disadvantages that reformers should consider as they design new institutions, even when adopting a systemic approach.

We organise the article as follows. The next section reviews relevant portions of the academic literature on democratic innovations. We pay particular attention to the notions of displacement, venue shopping and countervailing power. Subsequent sections draw on extensive field research in Rio Grande do Sul in 2014, consisting of in-depth interviews, observation of public meetings, and archival research, to describe the functioning of the Sistema and PB's place within it, its origins and its general results. Then we examine online voting and whether it displaced offline participation, migration of social movements away from $\mathrm{PB}$, elite capture and the

\footnotetext{
${ }^{11}$ Benjamin Goldfrank and Aaron Schneider, Budgets and Ballots in Brazil: Participatory Budgeting from the City to the State (Brighton: Institute for Development Studies, 2002); Benjamin Goldfrank and Aaron Schneider, 'Competitive Institution Building: The PT and Participatory Budgeting in Rio Grande do Sul', Latin American Politics and Society, 48: 3 (2006), pp. 1-31; Danilo R. Streck, Edla Eggert and Emil A. Sobottka (eds.), Dizer a sua palavra: educação cidadã, pesquisa participante, orçamento público (Pelotas: Seiva, 2005).
} 
related dissolution of countervailing power. These sections draw on our qualitative research and on two original quantitative data sets, one consisting of municipal and regional data on offline and online voting and socio-demographic and political characteristics, and the other of individual-level data from surveys of PB delegates in two periods, allowing us to compare the profile of delegates under the unification approach (1999-2002) with that of delegates under the diversification approach $(2011-14) .^{12}$

We do not think the two different approaches by the state government were chosen only because of their perceived advantages or flaws in tackling the question of scale, but that they were also contingent on political circumstances and class struggles in Brazil. Thus, this case could be used to highlight several empirical and theoretical issues, such as the ideological changes that took place within the PT, its complex relationships to social movements and the party's dramatic weakening over the last decade. Or, more generally, it could illustrate how the balance of social forces affects the design of participatory institutions or how incentives encourage or discourage individuals and groups to engage in large-scale participatory processes. Here, however, we concentrate on one dimension of the case, namely the implications the experience of state PB in Rio Grande do Sul has for the systemic turn in deliberative and participatory democratic theory. We do not consider the other topics mentioned above irrelevant, but argue that our focus is especially pertinent as more cities and countries implement multichannel systems of public engagement and seek answers about combining online and offline venues for deliberation and mass participation.

\section{Advantages and Disadvantages of Deliberative and Participatory Systems}

Though their concerns and claims overlap in many ways, ${ }^{13}$ proponents of participatory democracy and of deliberative democracy offer different approaches to the question of scale. The former focus on creating a participatory society by offering 'opportunities for individuals to participate in decision-making in their everyday lives as well as in the wider political system' and reforming 'undemocratic authority structures' ${ }^{14}$ They reject the notion that participatory democracy requires all citizens to participate in all areas of public decision-making, instead suggesting that it means all are 'aware that they can participate at any time in a transparent and deliberative process as part of an empowered community of equals over issues of common concern'. ${ }^{15}$ When analysing specific institutions, participatory democrats tend to emphasise who is participating and how much power participants have over policies and over participatory institutions themselves. They therefore find PB compelling as a step towards creating a participatory society, especially as originally practised in Porto Alegre, where participants disproportionately hailed from

\footnotetext{
${ }^{12}$ The surveys are described below in the 'Displacement 1' section.

${ }^{13}$ Nicole Curato, John S. Dryzek, Selen A. Ercan, Carolyn M. Hendriks and Simon Niemeyer, 'Twelve Key Findings in Deliberative Democracy Research', Doedalus, 146: 3 (2017), p. 32.

${ }^{14}$ Carole Pateman, 'Participatory Democracy Revisited', Perspectives on Politics, 10: 1 (2012), p. 10.

${ }^{15}$ Gianpaolo Baiocchi and Ernesto Ganuza, Popular Democracy: The Paradox of Participation (Stanford, CA: Stanford University Press, 2016), p. 160.
} 
disempowered groups, held considerable influence over budget priorities and investment projects, and refined the general rules guiding the process each year. ${ }^{16}$

By looking at the range of participatory practices that often exist in contemporary societies, deliberative systems theory suggests other ways to handle scale. Theorists such as Mansbridge et al. expand the analysis of deliberation and participation from one single process - be it PB or the 'mini-publics' (see note 16) often referred to by deliberative democrats - to multiple channels, whether deliberative, participatory or representative. ${ }^{17}$ This is especially relevant for the diversification approach in Rio Grande do Sul, where the government explicitly attempted to create an integrated system with multiple channels for engagement by citizens and their associations. The systemic approach emphasises that not all democratic venues need have the same tasks or be of equal importance, stressing the division of labour among parts of the system. A common critique of participatory democracy is that it takes too much time to involve every member of a large polity in deliberations around every decision. ${ }^{18} \mathrm{~A}$ systemic approach, by contrast, stresses that in-depth discussions can occur in one place, negotiations in another, and decision-making in a third. The different parts of a deliberative system can complement or undermine each other. One part's strength might compensate for another part's weakness, as when one institution is better at facilitating high-quality discussion among smaller groups of people and others cater to mass participation in making decisions over the same issues. However, parts of the system might undermine each other instead, which Mansbridge et al. describe as 'displacement. ${ }^{19}$ An institution that looks like an exemplary form of deliberation on its own - like a mini-public or a representative policy forum - might displace broadbased participation channels if decision-makers give it more weight.

This systemic perspective has recently become more prevalent in studies of democratic innovations. ${ }^{20}$ One reason is that participatory and deliberative initiatives are increasingly becoming multichannel. Rio Grande do Sul's Sistema is one example, but during the same period similar systems were implanted in several cities and even attempted at the federal level in Brazil. Furthermore, growth in such systems in other countries, as well as channels of engagement based on new information and communications technology platforms, has led to a range of studies of online and hybrid participation. ${ }^{21}$ Paolo Spada and Giovanni Allegretti define

\footnotetext{
${ }^{16} \mathrm{By}$ the same token, they criticise deliberative democrats' favoured venues - mini-publics, i.e. assemblies of quasi-randomly selected citizens, demographically representative of the larger population - for reflecting existing inequalities and for being disconnected from and powerless over important policy decisions. See Pateman, 'Participatory Democracy Revisited', p. 9, and Baiocchi and Ganuza, Popular Democracy, pp. $44-5$.

${ }^{17}$ Jane Mansbridge, James Bohman, Simone Chambers, Thomas Christiano, Archon Fung, John Parkinson, Dennis F. Thompson and Mark E. Warren, 'A Systemic Approach to Deliberative Democracy', in Parkinson and Mansbridge (eds.), Deliberative Systems, pp. 1-26.

${ }^{18}$ Robert A. Dahl, After the Revolution? Authority in a Good Society (New Haven, CT: Yale University Press, 1990 [1973]).

${ }^{19}$ Mansbridge et al., 'A Systemic Approach', p. 3.

${ }^{20}$ Paolo Spada and Giovanni Allegretti, 'When Democratic Innovations Integrate Multiple and Diverse Channels of Social Dialogue: Opportunities and Challenges', in Marco Adria (ed.), Using New Media for Citizen Engagement and Participation (Hershey, PA: IGI Global, 2020), pp. 35-59.

${ }^{21}$ Rosa Borge, Clelia Colombo and Yanina Welp, 'Online and Offline Participation at the Local Level', Information, Communication \& Society, 12: 6 (2009), pp. 899-928; Won No, Laurie Mook and Daniel
} 
multichannel democratic innovations as institutions that integrate messages and participatory spaces targeted to different segments of the population in a system specifically designed to increase and deepen citizen participation in the political decision-making process'. ${ }^{22}$

Some of the purported benefits of multichannel innovations include their ability to attract more participants than do single venues, such as face-to-face PB. They are also potentially more resilient (if one channel fails, others may prevail), and can enhance political inclusion of disadvantaged groups. Such systems can gain efficiency by sharing knowledge and resources across channels, and participants have more freedom to choose which issues they wish to address. ${ }^{23}$ Despite potential benefits, the introduction of new channels can also backfire. As with deliberative systems theory, Spada and Allegretti fear that one or more channels in the system might displace others, though they do not use the term 'displacement' ${ }^{24}$ The most relevant dangers for our case concern competition between and within channels. Different channels of engagement may compete for active participants, leading some channels to wither, and for funding, leading to a cannibalisation of resources that could weaken the whole system's functioning.

In our terms, the key displacement risks to $\mathrm{PB}$ when integrated into a larger system are two-fold: that $\mathrm{PB}$ gets displaced by other channels and that, within $\mathrm{PB}$, elite groups displace citizens and civic associations. We call this 'displacement' and not 'replacement' because PB's primary normative attraction is that often its distinguishing feature is to give equal or even greater voice to disadvantaged and previously disenfranchised groups. ${ }^{25}$ This is the case in cities where active community associations mobilise residents in poor neighbourhoods to participate in assemblies. $^{26}$ Displacement of poorer participants could be particularly pronounced when $\mathrm{PB}$ is combined in a multichannel system that includes online options, which typically show higher rates of participation by wealthier and more highly educated sectors of society. ${ }^{27}$ The digital divide suggests that online political participation amplifies pre-existing societal exclusion, and thus potentially represents an obstacle to this form of scaling up, especially in Latin America where both the

\footnotetext{
Schugurensky, 'Concurrent or Integrated Hybridity? Exploring Offline and Online Citizen Participation in Invited Spaces', International Journal of Organization Theory \& Behavior, 19: 4 (2016), pp. 514-34; Michael Touchton, Brian Wampler and Paolo Spada, 'The Digital Revolution and Governance in Brazil: Evidence from Participatory Budgeting', Journal of Information Technology \& Politics, 16: 2 (2019), pp. 154-68.

${ }^{22}$ Spada and Allegretti, 'When Democratic Innovations Integrate Multiple and Diverse Channels of Social Dialogue', p. 39.

${ }^{23}$ Ibid., pp. 41-4.

${ }^{24} I$ Ibid., pp. 44-6.

${ }^{25}$ Luciano Fedozzi, Adriana Furtado, Valéria Dozolinha Sartori Bassani, Carlos Eduardo Gomes Macedo, Cidriana Teresa Parenza and Milton Cruz, Orçamento participativo de Porto Alegre: Perfil, avaliação e percepções do público participante (Porto Alegre: Prefeitura Municipal de Porto Alegre et al., 2013) (available at http://lproweb.procempa.com.br/pmpa/prefpoa/observatorio/usu_doc/livro_op.pdf, last accessed 11 July 2020); Brian Wampler, 'Participatory Budgeting: Core Principles and Key Impacts', Journal of Public Deliberation, 8: 2 (2012), pp. 1-13.

${ }^{26}$ Leonardo Avritzer, 'New Public Spheres in Brazil: Local Democracy and Deliberative Politics', International Journal of Urban and Regional Research, 30: 3 (2006), pp. 623-37.

${ }^{27}$ Rafael Cardoso Sampaio, 'Instituições participativas online: um estudo de caso do Orçamento Participativo Digital', Revista Política Hoje, 20: 1 (2011), pp. 467-512.
} 
digital divide and inequality are already significant problems. The availability of digital tools does not have to mean anything other than different segments of the population choosing different channels, but it becomes a problem if online participation carries more weight than the participatory venues based on physical presence. Spada and Allegretti provide examples of $\mathrm{PB}$ in which priorities chosen by lower-class in-person participants were overturned by middle-class 'e-participants' in Brazil and of younger online participants reversing the results of in-person votes by senior citizens in Italy, leading to protests and suspension of PB, respectively. ${ }^{28}$

Displacement by elites within PB can also occur without online channels. Indeed, $\mathrm{PB}$ is especially vulnerable to the erosion of what is often called 'countervailing power. ${ }^{29}$ Several studies show how cases of successful $\mathrm{PB}$ depend on active participation by civil-society organisations like neighbourhood associations, social movements, and even trade unions. Such organisations mobilise participants locally, contribute to enlightened deliberations on budget issues, coordinate the actions of multiple community associations taking part in the process, negotiate between various interests, communicate local demands and needs to higher levels, and lastly - but importantly - pressure government institutions to share their power if they are reluctant. ${ }^{30}$ One key to success for Porto Alegre's original PB, according to Gianpaolo Baiocchi and Ernesto Ganuza, was that it 'was the only connector between citizenry and local state, and everybody - rich or poor, organized or unorganized - had to debate their proposals within the new structured public sphere. ${ }^{31}$

When participatory forums operate in a complex web of institutional arrangements, this creates the possibility of 'venue shopping'. This concept, originally coined by Frank Baumgartner and Bryan Jones, ${ }^{32}$ refers to the fact that not only interest groups like neighbourhood associations and trade unions but also professional organisations, public institutions and government agencies are strategic actors who seek venues that offer the best prospects for reaching their policy goals. If participants from such groups cannot obtain their goals in one setting, they may press their interests in more favourable venues. ${ }^{33}$ When working-class social movements migrate to other deliberative or participatory channels, this

\footnotetext{
${ }^{28}$ Spada and Allegretti, 'When Democratic Innovations Integrate Multiple and Diverse Channels of Social Dialogue', p. 45.

${ }^{29}$ Archon Fung and Erik Olin Wright, 'Countervailing Power in Empowered Participatory Governance', in Fung and Wright (eds.), Deepening Democracy, pp. 259-90; John Kenneth Galbraith, American Capitalism: The Concept of Countervailing Power (New Brunswick, NJ: Transaction Publishers 1993 [1952]).

${ }^{30}$ Rebecca Neaera Abers, Inventing Local Democracy: Grassroots Politics in Brazil (Boulder, CO, and London: Lynne Rienner, 2000); Gianpaolo Baiocchi, Patrick Heller and Marcelo K. Silva, Bootstrapping Democracy: Transforming Local Governance and Civil Society in Brazil (Stanford, CA: Stanford University Press, 2011); Brian Wampler, Participatory Budgeting in Brazil: Contestation, Cooperation, and Accountability (University Park, PA: Penn State University Press, 2007).

${ }^{31}$ Gianpaolo Baiocchi and Ernesto Ganuza, 'Participatory Budgeting as if Emancipation Mattered', Politics \& Society, 42: 1 (2014), p. 38.

${ }^{32}$ Frank R. Baumgartner and Bryan D. Jones, Agendas and Instability in American Politics, 2nd edn (Chicago, IL: University of Chicago Press, 2009), pp. 36-7.

${ }^{33}$ This is also referred to as 'forum shopping' by Archon Fung and Erik Olin Wright, 'Thinking about Empowered Participatory Governance', in Fung and Wright (eds.), Deepening Democracy, p. 35.
} 
opens up PB for elite capture. Powerful established actors can then hijack the channel and weaken the overall democracy-enhancing elements of the system.

In cities with weak associations, municipal administrations often exert great control over participatory processes, to the detriment of citizens. ${ }^{34}$ Egon Montecinos argues that PB in Latin American countries outside of Brazil typically fails to become a complement to representative institutions precisely because of the lack of countervailing power. ${ }^{35}$ This is a frequent trajectory for many externally initiated participation initiatives. When communities lack the capacity to utilise the processes in their own favour, local elites often take them over. ${ }^{36}$ As PB continues to spread across Latin American cities and gets scaled up and combined with other, often online, participatory venues, implementers face common challenges of minimising the digital divide, avoiding displacement, and elite capture. In Rio Grande do Sul's Sistema, PB was not externally initiated and in fact had a history of strong social-movement involvement; theoretically, it stood a chance of preventing displacement and erosion of countervailing power even if combined with new channels. The next sections examine the creation of the Sistema and what happened to PB in practice.

\section{The Sistema and PB in Rio Grande do Sul}

When the left-oriented Tarso Genro from the PT was elected governor of Rio Grande do Sul in 2011, his administration formalised a Sistema Estadual de Participação Popular e Cidadã (State System of Popular Citizen Participation) that included not only PB but multiple participation mechanisms, both online and offline, and explicitly combined representative and participatory democracy. In each of the years 2011-14, more than a million citizens voted in the final phase of the Sistema's budget process. In 2013, the Sistema won first place in Latin America in the United Nations Public Service Awards in the category 'Fostering participation in public policy decision making through innovative mechanisms. ${ }^{37}$ The Sistema's new digital participation tools won four national prizes and a World Bank prize for innovation and e-governance, and were featured alongside PB by The Economist. ${ }^{38}$ Brazil's then national government - which, like Genro, was of the PT - used Rio Grande do Sul's Sistema experiment as a guide to develop its own national-level participation system. ${ }^{39}$

The Sistema consisted of four different axes providing channels of engagement: budget decisions, social monitoring, social dialogues and digital participation. The

\footnotetext{
${ }^{34}$ Avritzer, 'New Public Spheres in Brazil'.

${ }^{35}$ Egon Montecinos, 'Democracia y presupuesto participativo en América Latina. La mutación del presupuesto participativo fuera de Brasil', Revista del CLAD: Reforma y Democracia, 53 (2012), pp. 12-13.

${ }^{36}$ Ghazala Mansuri and Vijayendra Rao, Localizing Development: Does Participation Work? (Washington, DC: World Bank, 2013), chapters 3 and 4.

${ }^{37}$ UNPAN, 'List of Winners for the 2013 United Nations Public Service Awards Held in Manama, Bahrain in June 2013' (2013).

${ }^{38}$ Processing Power', The Economist, 30 March 2013; Vinicius Wu, 'Gabinete digital: metodologías inovadoras em consultas públicas online', VI Congresso CONSAD de Gestão Pública (Brasília: CONSAD, 2013).

${ }^{39}$ CEBRAP, 'Relatório: $1^{\circ}$ Seminário Nacional de Participação Social' (São Paulo: Centro Brasileiro de Análise e Planejamento, 2013), pp. 17-18, available at https://cdes.gov.br/jspui/bitstream/11451/894/1/ Relat\%C3\%B3rio\%20do\%20I\%20SNPS.pdf (last accessed 4 Aug. 2020).
} 
first axis refers to $\mathrm{PB}$, the second to various rights-based and sectoral councils representing voluntary organisations at all levels of government, the third to a wide range of forums where multiple actors discuss policy issues with state officials, and the fourth to new forms of online participation (see Figure 1).

For the budget process, the Sistema generally adhered to the cycles and mechanisms used under previous governments, but with its own particular combination and additions. One novelty was the state's formulation of a four-year budget plan through a series of open meetings where government officials, public institutions and civic associations deliberated over investment guidelines to set the boundaries for subsequent budget discussions. These discussions started with 28 regional forums that reviewed results of previous budget years, assessed regional needs and initiated debate over priorities. Each regional forum also elected a commission that facilitated the process within its borders and sometimes set rules for how to distribute funds within the region. In subsequent local assemblies in the state's 497 municipalities, residents could submit and discuss investment proposals, select the prioritised budget areas of the municipality, and elect delegates. These delegates later met in regional plenaries to finalise budget proposals and the ballot for the popular vote. The vote took place over several days, both in physical ballot stations in the municipalities and online via personal computers and mobile devices. The number of votes determined the prioritised investments within each region and municipality, and redistributive rules based on a regional development index determined the allocation of resources to the regions (see Figure 2).

Several differences between the state's original PB from 1999 to 2002 and the Sistema budget process from 2011 to 2014 stand out. ${ }^{40}$ One is that, in the Sistema version, the participants in the public assemblies who diagnosed the regional and municipal problems and developed and discussed proposals were not the only citizens who voted on those proposals; rather, voting took place at a later date, and internet voting was added. Second, the state-wide PB council and regional committees that previously gave continuity to the process and oversaw budget implementation played minimal oversight roles in the Sistema. Moreover, $\mathrm{PB}$ voters and participants in the Sistema decided over a significantly smaller amount of budgetary resource than in the earlier PB. Whereas the original PB encompassed all state investments, or 4.1 per cent of overall state revenues, the funds available in the Sistema made up one-tenth of state investments, or 0.4 per cent of revenues. ${ }^{41}$ Nonetheless, the number of voters in the Sistema's budget

\footnotetext{
${ }^{40}$ Other differences include how the ballot was prepared and the range of options for voters. Under Olívio Dutra (governor, 1999-2002), ballots were drawn up and voted upon in municipal assemblies by all participants, which regional and state committees used to finalise the investment plan; under Genro, municipal assembly attendance was much sparser, and regional delegates condensed the demands from those assemblies into 10-20 items for the ballot to be voted upon in the subsequent referendum. Unlike in the Dutra era PB, the ballot did not include state-wide investments under Genro, and even though the ballot contained a field where voters could choose between a few large regional projects called 'Campo 2' - such as hospitals or education programmes - this was only suggestive and not binding on the government.

${ }^{41}$ Our calculations are from the state government's 'Transparency Portal' (http://www.transparencia.rs. gov.br) and Liderau do Santos Marques Júnior, Sabino da Silva Porto Júnior and Stefano Florissi, 'Processo Orçamentário no Estado do Rio Grande do Sul: uma proposta alternativa de participação popular na eleboração e fiscalização do orçamento público estadual', Revista de Economia Contemporânea, 8: 2 (2004), pp. 317-49.
} 


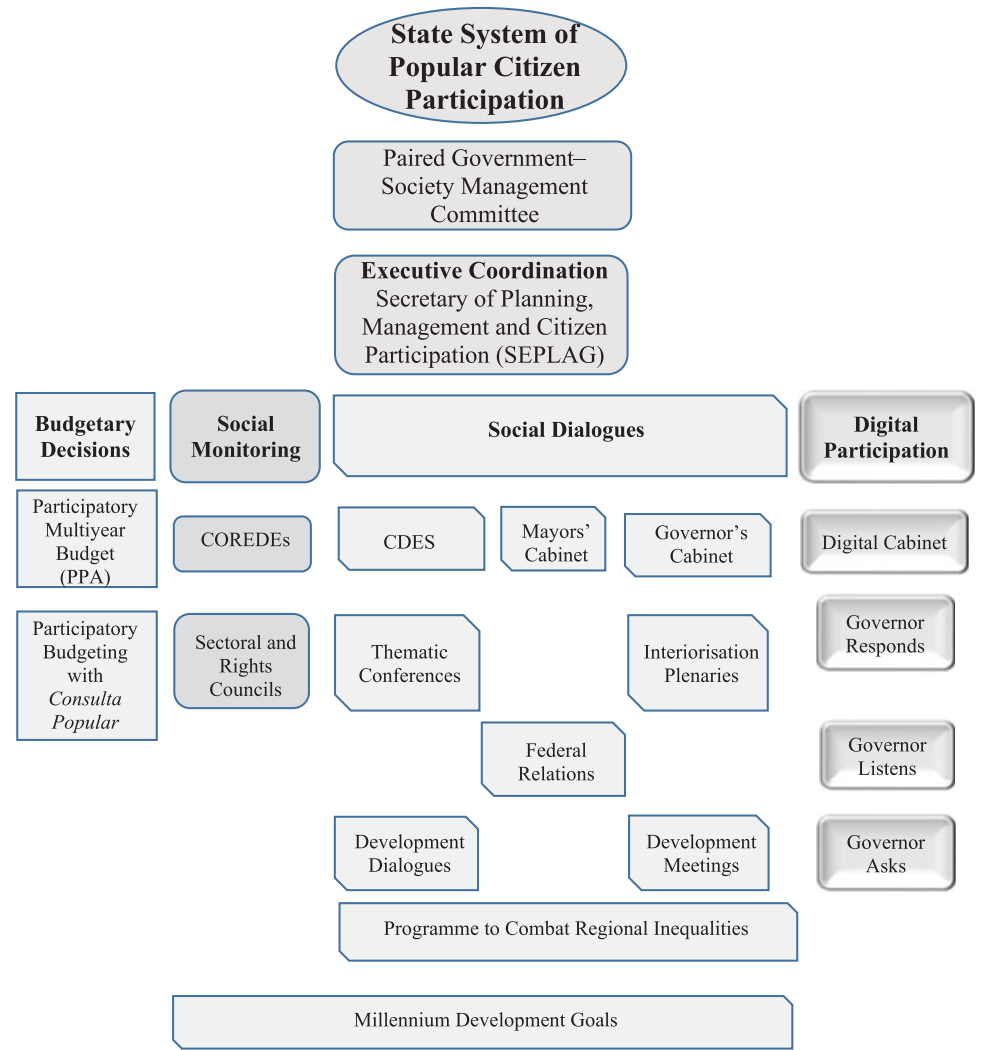

Figure 1. Institutional Design of the Sistema

Source: Translated and adapted from Governo do Rio Grande do Sul, 'Sistema Estadual de Participação Popular e Cidadã' (Porto Alegre: SEPLAG, 2012), p. 11 (available at https://estado.rs.gov.br/upload/arquivos/20170628/sistemade-participacao.pdf, last accessed 9 July 2020). The design is described as 'under construction'.

process was far higher than under the earlier PB. In 2014, 1.3 million individuals or 15.2 per cent of the electorate - voted, compared to 378,340 participants (nearly 7 per cent of the electorate) in $2001{ }^{42}$ These numbers, however, cannot be directly compared as a sign of the Sistema's popularity. Participating in the earlier PB was more costly than under the Sistema. Citizens previously had to set aside time and sometimes money for travel to and from a meeting that lasted three to four hours. In the Sistema, voters could simply go to the nearest ballot station (offline vote) or conveniently vote online from home or work, or wherever they happened to be with a smartphone or laptop (online vote). ${ }^{43}$

\footnotetext{
${ }^{42}$ For 2014, see Jonathan Mellon, Tiago Peixoto and Fredrik M. Sjoberg, 'Does Online Voting Change the Outcome? Evidence from a Multi-Mode Public Policy Referendum', Electoral Studies, 47 (2017), table 1, p. 15. For 2001, see Goldfrank and Schneider, 'Competitive Institution Building', p. 16.

${ }^{43}$ In a small number of municipalities, there were computer stations for voting as well, and these counted as online votes.
} 
Figure 2. Participatory Budget Process 2013

Source: SEPLAG et al., Sistema estadual de participação (see note 64$)$, pp. $40-2$.
Regional Plenaries

(April-May, 28 regions)

Regional diagnostics and preliminary debates

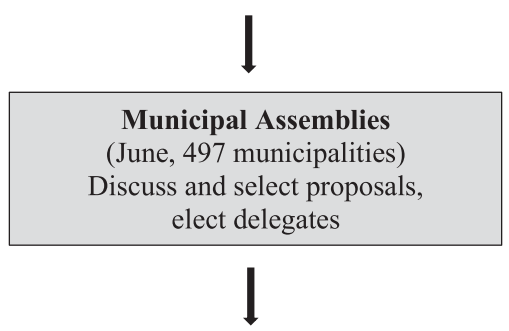

Regional Fora of Delegates (July, 28 regions)

Finalise proposals and ballot

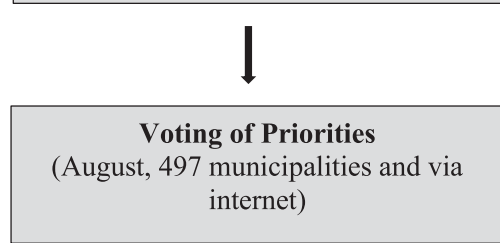

\section{The Roots of the Sistema}

Multiple causes underlie the PT government's change from the unification approach under Governor Olívio Dutra (1999-2002) to the diversification approach of Governor Genro (2011-14) and his creation of the Sistema. One was the proliferation of extra-parliamentary, power-scrutinising mechanisms in Brazil after the transition to civilian rule in 1985, which the Sistema recognised and attempted to incorporate. Another was the PT's appeal to the political centre, including the move from the 'petista (PT) way of governing' that focused on social movement protagonism, to 'lulismo': gradual reforms for the poor and conservative pacts with the rich, while relying on Lula's personal charisma. Ultimately, the establishment of the Sistema was also an intentional act, as government officials deemed it a better response to the challenges of complexity and scale than the original PB.

The growth of power-scrutinising institutions is part of what John Keane describes as a transition from representative to 'monitory democracy' - a society in which 'people and organisations that exercise power are now routinely subject to public monitoring and public contestation by an assortment of extraparliamentary bodies. ${ }^{44}$ This is not unique to Brazil, though it has been at the forefront of this development in Latin America, especially but not exclusively under PT governments. ${ }^{45}$ Following redemocratisation, not only participatory budgeting but

\footnotetext{
${ }^{44}$ John Keane, The Life and Death of Democracy (London: Simon \& Schuster, 2009), pp. 689-90.

${ }^{45}$ J. Ricardo Tranjan, Participatory Democracy in Brazil: Socioeconomic and Political Origins (Notre Dame, IN: Notre Dame Press, 2015).
} 
also a raft of other mechanisms such as sectoral councils ${ }^{46}$ and policy conferences proliferated throughout Brazil. ${ }^{47}$ In Rio Grande do Sul, for example, the number of state-wide public policy councils representing social movements as well as business and labour interests grew substantially during and after the Dutra period. They nearly doubled from 16 under Dutra to 29 under Genro, and the number of representatives in these institutions increased even more, from 154 to $455 .{ }^{48}$ Moreover, by law all municipalities must establish health, education, youth and social assistance councils, and many have multiple other policy councils as well. A mid-size municipality like São Leopoldo (214,210 inhabitants) has 20 official councils alone, but it is not uncommon for even small rural towns to have more councils than those that are mandatory. By 2013, municipal policy councils were estimated to number 60,000 across the country. ${ }^{49}$

The Sistema's creators sought to impose coherence on this pre-existing plethora of extra-parliamentary bodies in Rio Grande do Sul. The state government intended to integrate $\mathrm{PB}$ and digital participation with the many councils and forums already in operation. ${ }^{50}$ State officials expected these channels to complement and strengthen each other in order to improve the use of deliberative processes and generate better budgetary decisions:

The idea of a system contributes to the quality of the budget discussion. Why? When all of the deliberations in the social monitoring and dialogue axes arrive in the budget axis, the budget decisions we make become better. [...] In the social monitoring and social dialogue axes the discussion can go on 365 days a year. These deliberations enter a budget process that [...] has a limited time period [...]. This may improve the quality of the discussions in the budget assemblies. ${ }^{51}$

The change from the unification to the diversification approach in Rio Grande do Sul also mirrors the changes within the PT at the national level regarding participation. During the 1990s and early 2000s the PT championed a 'petista way of

\footnotetext{
${ }^{46}$ Michael Touchton, Natasha Borges Sugiyama, and Brian Wampler, 'Democracy at Work: Moving beyond Elections to Improve Well-Being', American Political Science Review, 111: 1 (2017), pp. 68-82.

${ }^{47}$ Thamy Pogrebinschi, 'The Squared Circle of Participatory Democracy: Scaling up Deliberation to the National Level', Critical Policy Studies, 7: 3 (2013), pp. 219-41.

${ }^{48}$ Tarson Núñez, 'Sociedade civil, política e democracia: experiências de participação no Rio Grande do Sul 1989-2014', Ph.D. dissertation, Universidade Federal do Rio Grande do Sul, 2016, pp. 143, 151.

${ }^{49}$ Touchton et al., 'Democracy at Work', p. 72.

${ }^{50}$ Davi Luiz Schmidt and Maria da Glória Lopes Kopp, 'Sistema estadual de participação cidadã: avanços e possibilidades de uma experiência subnacional', in Fernanda Costa Corezola, Aida Griza and Marília Patta Ramos (eds.), Políticas públicas: monitoramento, avaliação, controle e participação social no governo do Rio Grande do Sul (Porto Alegre: Editora da UFRGS/CEGOV, 2015), p. 145.

${ }^{51}$ Interview with 'Felipe', Director of Office for Citizen Participation at Secretaria de Estado de Planejamento, Gestão e Participação Cidadã (State Secretariat for Planning, Management and Citizen Participation, SEPLAG), Porto Alegre, Rio Grande do Sul, 16 Jan. 2014. We conducted 51 interviews with Sistema participants, government officials and union and opposition actors. The interviews were conducted face to face with a semi-structured interview guide and most lasted 1-2 hours, with some running shorter. Most interviewees are anonymised in this article, but some can be indirectly identified. This was clarified to and accepted by all interviewees, who gave their informed consent to this procedure.
} 
governing', based on a combination of public resource redistribution, transparent government and a robust role for social movements in public policy formation. PB was central to this orientation. ${ }^{52}$ The party's radical base hoped that 'Lula' Luiz Inácio Lula da Silva, elected president in 2002 - would advance 'petismo' throughout Brazil. Instead, PT governments focused on 'lulismo'. ${ }^{53}$ Participation changed from being strongly social-movement oriented to giving a range of interests a voice in public policy. $\mathrm{PB}$, for example, a central piece of the PT programme before Lula assumed the presidency in 2003 , was quickly discarded as unrealistic by the inner circles of the federal government. ${ }^{54}$ Instead, neo-corporatist councils that included civil-society organisations, government agencies, business interests and trade unions became the dominant type of extra-parliamentary policy venue. ${ }^{55}$ To a certain extent social movements demobilised as the PT gave their leaders jobs in the state apparatus and included them in the execution of federal programmes, inducing them to centre their activities around administrative tasks rather than pressure and protests. ${ }^{56}$

While PB in Porto Alegre and the first state PB were expressions of 'petismo', the Genro government's approach starting in 2011 resembled 'lulismo'. Genro's own writing and his coalition's campaign platform made the appeal to the political centre clear. Whereas Genro used to compare Porto Alegre's PB to the Paris Commune of $1871,{ }^{57}$ he later warned against 'the anarchy of assemblies' (anarquia assembleista) and argued that saving democracy required creating 'strategic programmatic points of agreement with a new centre, without which it is impossible to govern within democracy'. ${ }^{58} \mathrm{~A}$ decade earlier, the more radical Dutra government had focused on participation by disenfranchised sections of the population, the importance of social movements and the transfer of power to the grassroots. By contrast, Genro's programme emphasised that 'all segments of society' were to 'dialogue and construct' Rio Grande do Sul together, that state power should be shared among multiple agents, and that the protagonist was 'society' at large..$^{59}$ This move toward the centre partly stems from an understanding of Rio

\footnotetext{
${ }^{52}$ Benjamin Goldfrank and Brian Wampler, 'From Petista Way to Brazilian Way: How the PT Changes in the Road', Revista Debates, 2: 2 (2008), pp. 245-71; Gianpaolo Baiocchi, Einar Braathen and Ana Claudia Teixeira, 'Transformation Institutionalized? Making Sense of Participatory Democracy in the Lula Era', in Kristian Stokke and Olle Törnquist (eds.), Democratization in the Global South: The Importance of Transformative Politics (Basingstoke: Palgrave Macmillan, 2013), pp. 217-39.

${ }^{53}$ André Vitor Singer, Os sentidos do lulismo: reforma gradual e pacto conservador (São Paulo: Companhia das Letras, 2012).

${ }^{54}$ Hernán F. Gómez Bruera, 'The Governability Dilemma: Progressive Politics under Lula and the Brazilian Workers' Party', Ph.D. dissertation, University of Sussex, 2012, pp. 205-10.

${ }^{55}$ Hernán F. Gómez Bruera, 'Participation under Lula: Between Electoral Politics and Governability', Latin American Politics and Society, 57: 2 (2015), pp. 1-20; Ana Claudia Teixeira, 'Para além do voto: uma narrativa sobre a democracia participativa no Brasil (1975-2010)', Ph.D. dissertation, Universidade Estadual de Campinas, 2013, chapter 3.

${ }^{56}$ Hernán F. Gómez Bruera, 'Securing Social Governability: Party-Movement Relationships in Lula's Brazil', Journal of Latin American Studies, 47: 3 (2015), pp. 567-93.

${ }^{57}$ Tarso Genro, 'Orçamento Participativo e democracia', in Tarso Genro and Ubiratan de Souza (eds.), Orçamento Participativo: a experiência de Porto Alegre (São Paulo: Fundação Perseu Abramo, 1997).

${ }^{58}$ Tarso Genro, 'A questão democrática como questão da esquerda', Espaço Jurídico, 12: 2 (2011), p. 311.

${ }^{59}$ Unidade Popular pelo Rio Grande, 'Programa de Governo' (Comitê Estadual de Campanha, 2013), p. 8.
} 
Grande do Sul's past experiences with participatory institutions, which share a similar history with those elsewhere in Latin America of facing resistance from conservative sectors. Most importantly, when Dutra introduced state-level PB in 1999, opposition politicians combated the process vigorously, especially from the state legislature. ${ }^{60}$ The Genro administration's explicit appeal to combine participatory and representative institutions in the Sistema and its publicised use of digital communications technologies aimed at providing legitimacy and warding off condemnation from opposition parties and their elite supporters.

Finally, Genro's administration established the Sistema because government officials considered it a better response to governing at the scale of a state compared to the 'pure' PB model pursued under Dutra's unification approach. ${ }^{61}$ They also viewed Dutra's approach as outdated in relation to the new social complexities that developed after redemocratisation. Group interests became more diversified than before and, consequently, political views and values varied as well. Furthermore, new technologies altered the relationship between the state and the population. As expressed in one of our interviews:

The government cannot compress the intense calls of the population for more transparency and participation in only one instrument, in only one agenda, as in the case of participatory budgeting. In a municipality it is possible to do so, but at a regional scale this is too timid and very slow. The population has a much more intense pace of demanding things from the state, from the ruler, at this scale. You cannot subordinate this search for rights, this level of demand, into one rigid timeline, into only one 'ritual', in one instrument that goes on for a whole year. ${ }^{62}$

\section{Mixed Outcomes of the Sistema}

How did the Genro government's approach fare? While our focus is on what happens to $\mathrm{PB}$ once it is incorporated in a larger system, the establishment of the Sistema generally succeeded in appeasing potential conflicts with opponents in the legislative assembly and with pre-existing deliberative institutions. The relationship between the government and the legislative assembly was less turbulent in the Genro period than under Dutra. The opposition criticised the Genro administration for its handling of $\mathrm{PB}$, but never tried to sabotage $\mathrm{PB}$ as in previous years. The opposition's main objections to Genro's PB were that it promised more than it could deliver, that the government used it to pay for equipment and services that should be obligatory for the state to provide, and that it employed partisan coordinators who did political work instead of facilitating citizen participation. The same can be said of the government's relationship with the already existing

\footnotetext{
${ }^{60}$ Cláudia Feres Faria, 'Fóruns participativos, controle democrático e a qualidade da democracia no Rio Grande do Sul: a experiência do governo Olívio Dutra (1999-2002)', Opinião Pública, 12: 2 (2006), pp. 378-406; Goldfrank and Schneider, 'Competitive Institution Building'.

${ }^{61}$ To be sure, under Dutra PB was not the sole channel of citizen engagement with the state. Other channels existed, but the Dutra administration prioritised PB as the main venue for presenting and debating major public policies requiring new state funding.

${ }^{62}$ Interview with 'Leonardo', SEPLAG, Porto Alegre, Rio Grande do Sul, 22 April 2014.
} 
Conselhos Regionais de Desenvolvimento (Regional Development Councils, COREDEs), which traditionally played a role in the state's budget process. At the central level, the government and the COREDEs cooperated in carrying out PB and negotiated if they had differences on any changes introduced. Each side described this accord as one in which they acknowledged each other's different positions, but eventually reached consensus on difficult issues. However, several regional councils complained that the government coordinators overran the COREDEs and engaged mainly in partisan politics. ${ }^{63}$

The Sistema offered a more diverse set of deliberative channels than did PB under the Dutra government, and allowed for more in-depth participation by interested citizens and relevant organisations. At the state level, the social monitoring axis contained 33 councils, of which 29 had representation from civil-society associations. In the social dialogue axis there were 36 thematic conferences that relied significantly on social-movement participation, many of them based on local forums held prior to each state conference. ${ }^{64}$

At the same time, $\mathrm{PB}$ provided a form of direct participation that none of the more deliberative channels offered. The integration of $\mathrm{PB}$ with the rest of the Sistema, however, remained opaque. Even though state officials tried to establish procedures that would create a spill-over effect from deliberations in other channels into the budget process, this rarely happened. Although members of policy councils frequently participated in local PB assemblies, we never encountered examples where either council members or other participants spoke of these two channels being integrated in any way. In practice, PB was isolated from the other channels. Interaction with other axes was informal and accidental. Near the end of Genro's term, those in charge of organising the Sistema admitted that they never managed to integrate its various elements into a coherent structure. ${ }^{65}$ As a former government official, who had served in several PT administrations at the municipal and state levels, told us:

The governor's digital processes - Governor Asks, Listens, Responds - were not articulated with the $\mathrm{PB} /$ Consulta [Popular] or with the Development Council [CDES]. All the participatory channels were going on simultaneously and under different leaders, different secretaries, so there was no real system. These leaders came from different political currents and had different political projects, so they didn't work together. ${ }^{66}$

In sum, the Sistema largely met the Genro administration's goals of helping to reduce conflict with the opposition and of diversifying channels of citizen engagement, though it did not effectively synchronise these channels. Instead, PB was isolated. What about the outcome for PB? Did the addition of the online option and

\footnotetext{
${ }^{63}$ Interview with 'Lucas', President of the Fórum Estadual (Statewide Forum) of the COREDEs, Porto Alegre, Rio Grande do Sul, 8 April 2014; and Legard's observation of a meeting of the Forrum Estadual of the COREDEs, Porto Alegre, Rio Grande do Sul, 13 March 2014.

${ }^{64}$ SEPLAG et al., Sistema estadual de participação: construção e desafios (Porto Alegre: SEPLAG, 2014).

${ }^{65}$ Interview with 'Felipe', 16 Jan. 2014.

${ }^{66}$ Interview with Tarson Núñez, Advisor for International Relations and Cooperation, Cabinet of the Governor, Ufa, Bashkortostan (Russia), 23 Sept. 2017.
} 
the presence of other channels diminish PB's ability to give voice to the disenfranchised and to serve as a countervailing power?

\section{Adding Channels: Online Participation}

With respect to whether adding an online option weakened the voice of regular, 'offline' participants, we can fairly categorically state that online voting did not displace traditional PB participation. Instead, the online option largely attracted a separate group of participants, many of whom might not have participated otherwise, thereby boosting participation in general. As shown in Table 1, both offline and online voting state-wide increased during the period 2011-14. The number of online voters nearly doubled during the Sistema period (with an 88 per cent increase), while the number of in-person voters increased by 6 per cent. Most PB voters continued to vote in person; by 2014, slightly less than 20 per cent of PB voters chose the online option.

Examining variation in municipal-level participation rates provides additional evidence that online voters did not displace offline participation. In 55 of the 497 municipalities, over half of $\mathrm{PB}$ voters chose the online option, and this rate ranged from less than 1 per cent in nine municipalities to 100 per cent in three municipalities. To test the effects of online participation on offline participation, we conducted regression analyses of the absolute numbers of offline participants in the 497 municipalities in 2014. As shown in Table 2, the number of online voters that year is positively correlated and statistically significant even when controlling for several other significant predictors, such as population, distance from Porto Alegre (significant because this is the state capital and had used PB since 1989, and towns that are closer to it tend to have higher participation rates), vote share for Genro in 2010, and an indexed score on sanitation, which includes measures for the percentage of domiciles connected to the water and sewage systems and the average number of inhabitants per domicile. ${ }^{67}$ These results suggest that, generally, interest in online PB participation does not detract from offline PB participation; instead, both types of participation mostly fell and rose together. In particular, 2014 saw an increase (compared with the previous year) of over 98,000 online participants and over 92,000 offline participants.

Our quantitative findings are consistent with reports from our interviewees and with individual-level survey research. Government officials told us that in 2014 they led an intensive get-out-the-vote effort targeting both potential online and offline voters. Their strategy included use of social networks, principally Facebook and Twitter, sending vans with computers and an internet connection to several municipalities, and mobilisation via a network of government agents in each region. ${ }^{68}$ An interesting study by Jonathan Mellon et al. also indicates no displacement

\footnotetext{
${ }^{67}$ We also conducted regression analyses with change in the number of offline participants between 2011 and 2014 as the dependent variable and found similar results. The main independent variable of interest was the change in the number of online participants, and we found that, in both bivariate and multivariate regression analyses, it was positively correlated with the change in the number of offline participants and statistically significant, though we found fewer significant predictors and a lower $\mathrm{R}^{2}$ in that model.

${ }^{68}$ Interview with Tarson Núñez, 23 Sept. 2017.
} 
Table 1. Offline and Online Votes for Budget Priorities (2011-14)

\begin{tabular}{lcccc}
\hline Year & 2011 & 2012 & 2013 & 2014 \\
\hline Offline votes & 998,145 & 907,146 & 967,610 & $1,059,842$ \\
\hline Online votes & 135,996 & 119,603 & 157,549 & 255,751 \\
\hline Percent of votes online & $12.0 \%$ & $11.6 \%$ & $14.0 \%$ & $19.4 \%$ \\
\hline
\end{tabular}

Source: SEPLAG et al., Sistema estadual de participação (see note 64); our calculations.

Table 2. Predictors of Offline Voters for Budget Priorities, by municipality (2014), absolute number of offline voters

\begin{tabular}{lc}
\hline Variable & Coefficient \\
\hline Online voters 2014 (number) & $0.7718^{\star \star \star}(0.169)$ \\
\hline Vote for Tarso Genro in 2010 as share of electorate & $8754.7^{\star \star \star}(2109)$ \\
\hline Population (1000 inhabitants) & $192.03^{\star \star \star}(21.68)$ \\
\hline Distance from Porto Alegre $(\mathrm{km})$ & $-2.9627^{\star \star}(0.951)$ \\
\hline Sanitation index & $5304.1^{\star \star \star}(880.2)$ \\
\hline PT members as share of population & $-8142.3(8325)$ \\
\hline PB spending per capita in 2012 & $3.3547(8.067)$ \\
\hline Constant & $-2997.9^{\star \star \star}(886.1)$ \\
\hline
\end{tabular}

Multiple linear regression. Unstandardised coefficients with standard errors in parentheses.

${ }^{\star \star \star} \mathrm{p}<0.001 ;{ }^{* \star} \mathrm{p}<0.01$; adjusted $\mathrm{R}^{2}=0.452$; valid $n=496$ (in some years, only 496 of the 497 municipalities reported participation data).

See text for explanation of variables.

Source: Data on online voters were downloaded from http://participa.gov.rs.br; votes for Tarso Genro and PT members as share of electorate from http://www.tre-rs.gov.br; PB spending data from http://consulta.popular.gov.rs.br; population, sanitation index and distance from Porto Alegre from http://feedados.fee.tche.br/feedados/. Some of these websites no longer exist; please consult authors for details.

through online voting. ${ }^{69}$ The team examined all PB votes, online and offline, in Rio Grande do Sul in 2014 and conducted surveys of online and offline voters in Porto Alegre, and report three major results. First, 'respondents who are male, university educated, less than 30 years old, or who use the Internet daily are more likely to vote online'. ${ }^{70}$ Second, roughly two-thirds of online voters surveyed reported they would not have voted in PB if there had been no online option. Together, these findings strengthen the impression that the online channel reaches a specific segment of the population that would not otherwise participate. Third, using a regression analysis of project proposals in the 28 regions, the team find that online vote choices are highly correlated with offline vote choices (the bivariate $\mathrm{R}^{2}=0.84$ ). ${ }^{71}$ This last result is surprising, given the different demographic profile of online voters, but similarly points to the online option's innocuous role. Voting, whether online or in person, is

\footnotetext{
${ }^{69}$ Mellon et al., 'Does Online Voting Change the Outcome?'

${ }^{70}$ Ibid., p. 17.

${ }^{71}$ Ibid., p. 18.
} 
a low-effort, low-salience act of participation. To better understand how the Sistema affected $\mathrm{PB}$, we need to study the key actors engaged in the crucial deliberative stages, and here we do find signs of displacement.

\section{Displacement 1: Social Movement Migration}

To examine the issue of who participates most actively in $\mathrm{PB}$ and to what extent the profile of participants changed when PB became part of the Sistema, we take advantage of PB regional delegate surveys from 2002 and 2014. ${ }^{72}$ Delegates are the most committed participants, those who deliberate over $\mathrm{PB}$ priorities and projects and create the ballot. Our survey data are taken from a strategic sample of five of the state's 28 regions: Litoral Norte, Médio Alto Uruguai, Serra, Sul and Vale do Rio dos Sinos. These regions are comparable for the two periods and are selected to represent the diversity of rich and poor, agricultural and urban, and densely and sparsely populated regions. Although the five regions constitute a small sample, they appear representative of the delegates as a whole. ${ }^{73}$

The survey data reveals a remarkable difference between the earlier state-level PB and the Sistema's PB: the widely diverging degree of social-movement participation. In the Dutra era's unification approach, $\mathrm{PB}$ had a substantial social-movement presence, in part as a reaction to opposition intransigence. When the state judiciary prohibited the government from using state resources to organise PB meetings in 1999 - following a conflict with the legislative assembly - social movements stepped up. The Central Única dos Trabalhadores (the major trade union federation, CUT), the Movimento dos Trabalhadores Rurais sem Terra (landless workers' movement, MST), the rural workers' unions the Confederação Nacional dos Trabalhadores Rurais Agricultores e Agricultoras Familiares (National Confederation of Rural Family Agricultural Workers, CONTAG) and the Federação dos Trabalhadores na Agricultura (Rural Workers' Federation, FETAG) decided to run PB assemblies themselves. Social movements remained active in PB throughout Dutra's term. Of the delegates in the selected regions in the 2002 survey, 34 per cent reported that they were affiliated with a trade union or civil-society association and 22 per cent that they were affiliated with a social movement. In Porto Alegre, a city with historically active civic associations, 54 per cent of state-wide PB delegates

\footnotetext{
${ }^{72}$ Benedito Tadeu César directed the 2002 survey at the Federal University of Rio Grande do Sul (UFRGS), described in César, 'Orçamento Participativo Estadual: Perfil Social e Político de seus Participantes', Paper presented at the VIII Congresso Luso-Afro-Brasileiro de Ciências Sociais, Coimbra, Portugal, 16-18 Sept. 2004. We are grateful to him for providing access to these data. Legard directed a group of UFRGS students to conduct the 2014 survey.

${ }^{73}$ The profile of the delegates in the five regions in the 2002 survey $(n=389)$ is largely similar to the profile of the delegates in the total of 19 regions in the same survey $(n=1409)$. The most notable differences are that the five-region sample has fewer public servants ( $4.2 \%$ difference). We assume that the difference between the delegates in our selected regions and the rest of the delegates is also largely similar in 2014 but were unable to test for this. We do not know the skewness for the 2002 survey as a whole, but probably delegates with weak organisational affiliation are underrepresented in the survey. In 2014 we faced the challenge that more people than elected showed up at some of delegate meetings and responded to our survey. This was especially a problem in one region (Serra). However, a sensitivity analysis shows that the results do not change if we exclude this region; we have therefore kept it in our results.
} 
in 2001 participated in a neighbourhood association, 14.5 per cent in a trade union, 14.7 per cent in a popular council and 9 per cent in an NGO. ${ }^{74}$

Under Genro's diversification approach, the relationship between social movements and $\mathrm{PB}$ changed. Organisations traditionally allied with the PT, such as CUT, MST, CONTAG and FETAG, were not opposed to the Genro government's PB. However, they put little effort into mobilising their members to participate. Of the delegates in our 2014 survey, only 16 per cent reported that they represented a trade union, social movement or other civil-society association. In Porto Alegre, the number of delegates from such associations was less than half of that in 2001. A government official described this relative absence as a 'distortion':

The trade unions participate little, and the rural movements - who are very strong in Rio Grande do Sul - could participate more. There are distortions. The rural movements are very organised, and at times they prefer to talk directly to the governor instead of participating here. And since the governor is preoccupied with rural issues, he sometimes establishes an advisor who acts as a middleman between the governor and the rural movements. And then they say: 'We won't participate [in PB] because we already manage to resolve these issues by other means.' These are distortions. ${ }^{75}$

One major reason for social-movement migration has to do with the Sistema - or rather, the Sistema plus the many other contact points between organised actors and the state that had developed after military rule ended in 1985 and that expanded further after the PT's presidential victory under Lula in 2002. The many councils and conferences encompassed by the Sistema came in addition to all the different forms of social-movement engagement built into diverse programmes of the various federal, state and municipal agencies that utilised participatory methodologies.

The rural workers' union FETAG exemplifies the kinds of opportunities and pressures this put on the social movements. Under the Sistema, FETAG participated in councils at the state and local level, in thematic conferences, and in a host of other spaces. These included frequent meetings and negotiations with the governor's staff and various ministries. FETAG also formed part of the government's 'Harvesting Plan' (Plano Safra) that encompassed programmes supporting small-scale producers and agribusiness - the implementation of which also relied on participation of rural communities. FETAG'S regional and local branches, for example, helped the state in distributing goods and performing services directed at their members, accompanied technical consultants visiting farms and cooperatives, and took part in various committees discussing the execution of government policies. In addition, FETAG trustees participated in regional forums for mayors and local council members, municipal partnerships, advisory councils for local banks and more.

At the local, regional and state levels, our interviewees also emphasised the importance of protests and other forms of action to put pressure on the

\footnotetext{
${ }^{74}$ Cláudia Feres Faria, 'O estado em movimento: complexidade social e participação política no Rio Grande do Sul', Ph.D. dissertation, Universidade Federal de Minas Gerais, 2005, p. 177.

${ }^{75}$ Interview with 'Felipe', 16. Jan. 2014.
} 
government and state legislature. This range of opportunities meant that social movements had to prioritise where to participate, and they emphasised those venues that best rewarded their members:

Most of the unions [in FETAG] are small and only have a president and some staff that does the bureaucratic part. When there are three meetings in three different places on the same day, they cannot participate in all of them and have to choose one. [...] We have to prioritise those that will attend most to the needs of the farmers. [...] Our number one priority is always that which reaches out to the highest number of families, in as many regions as possible $[\ldots] .{ }^{76}$

Social-movement migration away from PB cannot be explained by the existence of multiple participatory opportunities alone; the relatively scarce resources available in the Sistema's PB proved important as well. As previously shown, PB under Genro encompassed only a fraction of the state's budget. The resulting discouragement emerged as a recurring theme in our interviews with social-movement representatives. As explained by one FETAG leader:

Inside the trade union movement there are leaders who don't believe in the state PB any more, who don't vote, don't support it and don't come to the meetings. There are those pessimistic types who don't want to participate and collaborate any longer, because they already participated sometimes [in the past] and didn't manage to achieve what they expected to obtain. ${ }^{77}$

Associations like FETAG did not abandon PB altogether. Social-movement and civil-society organisation leaders still represented a minority of the PB delegates, and during our fieldwork we repeatedly encountered local FETAG employees or volunteers participating in PB assemblies and expressing support for PB. This ambiguous behaviour by FETAG can be understood from a venue shopping perspective. As Sarah Pralle stresses, strategic political actors seek venues not only to achieve substantive policy goals, but also to send messages to their members and the public, and to please allies. ${ }^{78}$ Due to the close relations between rural social movements and the PT more broadly, it is not unexpected to find activists from such movements participating to some extent in most of the venues created by PT governments.

As noted previously, the Sistema did not create, but rather formalised and tried to integrate, the multiplicity of extra-parliamentary mechanisms involving social-movement representation in Rio Grande do Sul. Nevertheless, both availability of new channels within the Sistema as well as PB's diminished centrality and clout help explain declining social-movement participation; in turn, as described below, this had negative consequences for giving voice to the disenfranchised.

\footnotetext{
${ }^{76}$ Interview with 'Bruno', statewide leader of FETAG, Porto Alegre, Rio Grande do Sul, 23 April 2014.

${ }^{77}$ Interview with 'Paulo', regional leader of FETAG, Porto Alegre, Rio Grande do Sul, 23 April 2014.

${ }^{78}$ Sarah B. Pralle, 'Venue Shopping, Political Strategy, and Policy Change: The Internationalization of Canadian Forest Advocacy', Journal of Public Policy, 23: 3 (2003), p. 241.
} 


\section{Displacement 2: Dissolution of Countervailing Power}

Under the Dutra government's unification approach, PB had served as the primary connector between citizens and the state, and encompassed all state investments. Moreover, it was generally portrayed as a central item in a new political project, uniting social movements and the PT. This made it an attractive venue for popular sector movements, who stayed loyal to PB and became a counterweight to the traditionally powerful actors who decided on budget resources. Right-wing governments continued to practise a version of PB under the label 'Consulta Popular' after Dutra; although we do not have data on social-movement participation in this consultation process, it is likely that popular sector movements significantly reduced their participation in this channel during those years. ${ }^{79}$ Under Genro's Sistema, however, the movements did not return to PB in full force. Instead they remained in, or migrated to, other channels with greater appeal. This opened up the budgeting axis to conventionally powerful actors - such as local political elites and relatively privileged public servants - who ended up dominating it. In fact, 67 per cent of the delegates in the Sistema represented a public institution - a municipality, an administrative office, a hospital, school or university. As described by Emil Sobottka and Danilo Streck, these public servants came 'to defend investments in [the] everyday needs [of their offices]. Nurses want funds for the needs of day-to-day health posts; public school teachers want to ensure that in their schools there are chalk, cleaning supplies and school meals; police officers in their uniforms claim cars to patrol the streets, and [body armour] to protect them. ${ }^{, 80}$ This influx of public servants profoundly altered the socio-economic profile of those who represented the participants in the process. As shown in Table 3, in contrast to the more popular and partisan profile of PB delegates elected under Dutra, the typical Sistema-era delegate was a middle-aged, highly educated, non-partisan man from the public sector. ${ }^{81}$ In sum, $\mathrm{PB}$ went from being a popular movement venue during the Dutra period to an intra-governmental elite phenomenon under Genro's Sistema.

The incentive structure of the PB venue favoured organised groups who could muster thousands of votes. When organised social movements reduced their activities, the countervailing power dimension of $\mathrm{PB}$ dissolved, letting public-sector workers and professional politicians take over. Municipalities that could muster the highest share of voters would get the largest amount of investment money even if this was tempered by rules that guaranteed more funds to the poorest municipalities regardless of voter turnout. What mattered most was getting projects on the ballot and then mobilising voters during the two or three referendum days at the end of the process. In order to encourage potentially 8 million electors to

\footnotetext{
${ }^{79}$ Igor Ferraz da Fonseca, 'Resiliência, escala e participação em governos de direita: uma análise da consulta popular, no Rio Grande Do Sul (1998-2018)', Opinião Pública, 25: 3 (2019), pp. 694-725.

${ }^{80}$ Emil A. Sobottka and Danilo R. Streck, 'When Local Participatory Budgeting Turns into a Participatory System: Challenges of Expanding a Local Democratic Experience', International Journal of Action Research, 10: 2 (2014), pp. 169-70.

${ }^{81}$ Additional regression analyses demonstrate that being a public servant is positively associated with having higher education levels, even when controlling for gender and age, in both periods, while being affiliated to a social movement is not a statistically significant predictor of higher education levels in the Dutra period and is negatively correlated with education levels in the Genro period, again controlling for gender and age.
} 
Table 3. Comparison of Characteristics of Budget Delegates under 'Pure' PB (2002) and the Sistema (2014) in Rio Grande do Sul

\begin{tabular}{lcc}
\hline & 2002 & 2014 \\
\hline Women & $40.8 \%$ & $33.4 \%$ \\
\hline Median age & 38 & 44 \\
\hline Primary or no education & $49.6 \%$ & $18.0 \%$ \\
\hline Secondary or higher education & $50.4 \%$ & $82.0 \%$ \\
\hline Public sector workers & $31.4 \%$ & $64.8 \%$ \\
\hline Partisan affiliation with the state government & $56.3 \%$ & $25.5 \%$ \\
\hline$n$ & 389 & 564 \\
\hline
\end{tabular}

Source: Surveys reported in the text and notes 72 and 73.

participate, the state government relied on the support of public officials involved in the process.

A large majority of the ballots were handed in physically (not online), and the task of collecting them was partly carried out by the municipalities and local organisations connected to the COREDEs, and partly by participating groups who received official ballot boxes and collected votes themselves. These interest groups used the opportunity to argue that voters should support their demands. This gave an advantage to large, organised groups. Institutions like schools and hospitals could convince students or patients to vote for their demands and use employees to collect votes during the referendum. Organisations like police and fire departments could use their trucks as mobile polling stations, and possibly also use their authority to encourage and influence voters. ${ }^{82}$ One fire brigade officer explained:

Interviewer: So, on the day of the referendum you all go out on the street to get votes?

'Igor': Yes, we go out with our trucks, go to the ballot places, talk to people. We put good pressure in the whole region.

Interviewer: So, you go to the ballot places to talk to the people to prioritise ...?

'Igor': We say 'yes' to the vote. We want to win the vote. The people who see the ballot don't understand much, but if they see a fire fighter who talks to them, they vote. Here we say that 'those who aren't seen, aren't remembered'. We have to sell our fish. We participate effectively. ${ }^{83}$

\footnotetext{
${ }^{82}$ Matt Halkin with Fredrik M. Sjoberg and Jonathan Mellon, 'Impact of Online Voting on Participatory Budgeting in Brazil', in Tiago Peixoto and Micah L. Sifry (eds.), Civic Tech in the Global South (Washington, DC: World Bank, 2017) describe multiple instances of public workers attempting to persuade passers-by to vote and to do so for particular projects (pp. 235, 282-3, 292-5).

${ }^{83}$ Interview with 'Igor', fire brigade officer and PB delegate, Torres, Rio Grande do Sul, 9 April 2014.
} 
An additional strategy for gaining votes was to make alliances with groups representing demands from other areas or municipalities. Groups representing a certain demand also encouraged voters to select their allies' demands on the ballot (voters could select up to four projects, allowing promotion of up to three other demands). Large organised interest groups also had the advantage here, in that they could engage in wide outreach on voting days, which made them attractive as allies of other interest groups. Such alliances often took place alongside the official process, further cementing the advantages of already powerful actors. As described by a mayor who was deeply engaged in PB:

After the municipal assembly we hold here, there is a new regional meeting of delegates. There, we have to negotiate. There, it's only negotiations. There, we coordinate a lot to make sure that our demands pass. Did you see how five municipalities [at the regional audience] voted for only one thing? They had already closed a deal. [...] We were left behind. [...] Even if we came with the largest delegation to that meeting, we lost this opportunity to coordinate with the others. Now, we have to negotiate with the other delegates in the region, and to vote both for things that are of interest for us and what is of interest for others. ${ }^{84}$

A former official in the Dutra and Genro administrations, Tarson Núñez, described the state $\mathrm{PB}$ as 'various sectors of the government fighting over the budget ... Government secretaries [Ministers] from the different areas mobilised their people, their constituencies - firefighters, farmers. ${ }^{85}$ Rather than serving as a popular counter-weight to the powerful, $\mathrm{PB}$ was transformed into an internal contest within the state government and between local governments.

\section{Conclusion: Displacements in Deliberative Participatory Systems}

The diversification approach to scale had some advantages in Rio Grande do Sul. It provided one solution to the perceived trade-off between deliberation and mass participation, by allowing in-depth policy discussion to take place in some channels and large-scale participation to occur in others. The introduction of online voting not only served as a tool to facilitate voting, but also as a channel tailored to younger middle-class segments of the population without displacing other participants. We have not focused on the deliberative and participatory system as a whole, however, but concerned ourselves with the trajectory of $\mathrm{PB}$ as one channel within a multichannel system. It fared less well, ending up isolated and diminished. PB is susceptible to venue shopping, and we argue that this is especially true in multichannel systems. Indeed, with the Sistema's multiple deliberative venues, this is what happened to state-level PB in Rio Grande do Sul from 2011 to 2014 under Genro. Social movements, which had played crucial roles supporting PB under Dutra, migrated to other venues, which reduced their engagement within PB. True enough, the Sistema did not create the multitude of extra-parliamentary mechanisms, but rather formalised and affirmed a trend that went on for nearly

\footnotetext{
${ }^{84}$ Interview with 'Camila', mayor and PB delegate, Torres, Rio Grande do Sul, 9 April 2014.

${ }^{85}$ Interview, 23 Sept. 2017.
} 
three decades. Migration away from PB had already partly occurred before Genro installed the Sistema. Nonetheless, the Genro administration did not manage to attract popular-sector social movements back into its budgetary channel but rather made them disperse their energies throughout even more participatory venues. This left $\mathrm{PB}$ vulnerable to already powerful groups, in this case local political elites and organisations of public servants. The outcome was the dissolution of countervailing power as social movements were displaced.

What can the case of Rio Grande do Sul tell us about the debate between theorists of deliberative and participatory democracy, the fate of the PT, and about the chances of scaling up local democratic experiments in Brazil and elsewhere? First, we repeat that both the unification and deliberation approaches to citizen engagement entail advantages and disadvantages, and that to some extent neither can properly resolve the trade-off between deliberation and mass participation. The unification approach associated with participatory democrats was stronger in Rio Grande do Sul when it came to including the needs, preferences and political projects of previously disenfranchised sectors of the population. On the other hand, it did not allow these participants to properly deliberate over issues of common concern, nor did it include them in the final decision-making organs. The diversification approach to scaling up examined here, which we link to deliberative systems theorists, had the advantage of opening venues for both collective will formation through social dialogues and public policy councils and direct, popular participation in the budgetary channel, but it overlooked the crucial aspect of uniting the social forces necessary to ensure that this mass participation channel was inclusive.

Second, neither deliberative nor participatory democrats offer an effective strategy for overcoming opposition to new democratic channels from the already powerful. The diversification approach runs the risk of weakening mass participation too much. It ensures inclusion of both incumbent and rival elites but ultimately disperses social-movement energies. On the other hand, the unification approach risks domination by ruling party partisans and fierce resistance from rival political elites.

Third, this dilemma remains unresolved for Latin American political movements as well. PT administrations under Genro, and under Lula and his successor Dilma Rousseff nationally, created multiple channels of deliberation but very few channels of mass participation, and the one channel of mass participation under Genro, $\mathrm{PB}$, was diminished. As others have argued, the mass protests starting in 2013 - which sprang up in Rio Grande do Sul as strongly as elsewhere in Brazil - suggest the insufficiency of the PT's efforts to create participatory institutions to channel popular-sector demands. ${ }^{86}$ To be sure, other contemporaneous attempts by left-leaning national governments in Latin America to expand participatory institutions fared no better, whether mass-based but partisan and clientelistic, as in Venezuela under Hugo Chávez, or multi-channel and deliberative but ultimately never implemented, as in Chile under Michelle Bachelet. ${ }^{87}$ With the recent rise of

\footnotetext{
${ }^{86}$ Evelina Dagnino and Ana Claudia Chaves Teixeira, 'The Participation of Civil Society in Lula's Government', Journal of Politics in Latin America, 6: 3 (2014), pp. 39-66.

${ }^{87}$ Benjamin Goldfrank, 'Participatory Democracy in Latin America? Limited Legacies of the Left Turn', in Manuel Balán and Françoise Montambeault (eds.), Legacies of the Left Turn in Latin America: The Promise of Inclusive Citizenship (Notre Dame, IN: Notre Dame Press, 2020), pp. 135-60.
} 
conservative presidents in much of the region, coupled with the resurgence of widespread protests in several countries, and now the COVID-19 pandemic and economic recession, the near-term outlook for participatory experiments is pessimistic.

Fourth, if and when conditions improve, future designers of multichannel democracies in Latin America and beyond will need to pay attention to avoiding displacement among and within channels and find better ways to balance deliberation and mass participation. Easy answers for how to do either of these tasks do not exist. In different, more propitious contexts - where government revenues are greater (or indebtedness smaller) and where political polarisation is less extreme - it may be easier to synchronise and sequence deliberative and participatory channels. Moreover, the institutionalisation of channels that truly allow for deliberation among ordinary citizens as well as empowered mass participation probably requires a large-scale mobilisation that is more akin to the movement that produced PB in the first place in Brazil in the late 1980s.

Acknowledgements. The authors would like to thank the three anonymous reviewers for their helpful feedback, Diana Kraiser Miranda for research assistance, and several colleagues who offered suggestions on earlier versions of some of the arguments made here: Kent Eaton, Yanina Welp, Aaron Schneider, Brian Wampler, Fredrik Engelstad, Cathrine Holst, Andrea Felicetti and Alison Post.

\section{Spanish abstract}

El presupuesto participativo (PP; 'PB', por sus siglas en inglés) ha sido una de las reformas democráticas locales más populares en Latinoamérica en las décadas recientes. Este artículo examina lo que le pasó al PP cuando fue elevado al nivel estatal e integrado en un sistema participativo en Rio Grande do Sul, Brasil (2011-14). Utilizando teorías de sistemas deliberativos, participación multicanal, 'venue shopping' (búsqueda de los foros más favorables) y contrapoder, así como un diseño de investigación multi-método, explicamos cómo el enfoque de sistemas permitió tanto la democracia deliberativa como la directa y movilizó a nuevos sectores para participar en línea. Sin embargo, por el lado negativo, los diferentes canales participativos se socavaron. Los movimientos sociales migraron a otros espacios, dejando el proceso presupuestal abierto al control de grupos bien establecidos y poderosos del sector público.

Spanish keywords: democracia participativa; democracia deliberativa; presupuesto participativo; Brasil

\section{Portuguese abstract}

Orçamento Participativo (OP; 'PB', das suas siglas em inglês) tem sido uma das reformas locais democráticas mais populares da América Latina nas últimas décadas. Este artigo examina o que aconteceu com o OP quando ele foi expandido ao nível estadual e integrado em um sistema participativo no Rio Grande do Sul, Brasil (2001-14). Fazendo uso de teorias de sistemas deliberativos, participação multicanal, 'venue shopping' (ou a prática de buscar locais que ofereçam as melhores perspectivas de alcançar objetivos políticos), e contrapoder, bem como uma elaboração de pesquisa multimétodo, explicamos como a abordagem do sistema estadual de OP não só facilitou a deliberação e a democracia direta, como também estimulou novos setores à participação online. No entanto, também trouxe consequências negativas, quando os diferentes canais de 
participação prejudicaram uns aos outros. Movimentos sociais migraram a outros espaços, deixando o processo orçamentário sob controle de grupos do setor público já bem estabelecidos e poderosos.

Portuguese keywords: democracia participativa; democracia deliberativa; orçamento participativo; Brasil

Cite this article: Legard S, Goldfrank B (2021). The Systemic Turn and Participatory Budgeting: The Case of Rio Grande do Sul. Journal of Latin American Studies 53, 161-187. https://doi.org/10.1017/ S0022216X20000954 